\title{
Determination of rate constant, binding constant, and binding number by fluorescence measurements of Gd3N@C80(OH)20 in D2O
}

\author{
Kyle C. Purrman ${ }^{\dagger}$ and A. A. Rodriguez* \\ ${ }^{\dagger}$ Brody School of Medicine, East Carolina University, Greenville, North Carolina, 27834 \\ ${ }^{\dagger}$ Purrmank10@students.ecu.edu \\ *Department of Chemistry, East Carolina University, Greenville, North Carolina, 27858 \\ *rodriguezar@ecu.edu
}

\section{ABSTRACT}

Today MRI imagining techniques are capable of discerning between abnormal and normal complex tissues by providing contrasting images of these tissues. One drawback of using MRI imagining is its low sensitivity. However, this sensitivity can be greatly enhanced by introducing contrasting agents who can provide a new pathway for water molecules to significantly relax faster and hence generate the desired "contrast" between healthy and unhealthy tissues. We report the first ever recorded fluorescence emission spectrum of $\mathrm{Gd}_{3} \mathrm{~N} @ \mathrm{C}_{80}(\mathrm{OH})_{20}$; where $-(\mathrm{OH})_{20}$ is the average number of hydroxyl groups. Our emission data indicates that the $\mathrm{H}_{2} \mathrm{O}-\mathrm{Gd}_{3} \mathrm{~N} @ \mathrm{C}_{80}(\mathrm{OH})_{20}$ interactions lead to fluorescence quenching via a static quenching mechanism. The binding constant, $\mathrm{K}_{\mathrm{b}}$, on the other hand, was found to be of the same magnitude as interactions between human serum albumin and small organic acid but quite different, several orders of magnitude smaller, than protein nanoparticle complexes. Interestingly, the binding number, $\mathrm{n}$, was found to be approximately 0.5 , which in cases like this, is rounded to a whole number of one. The data also indicated an extremely fast rate constant on the order of $10^{12} \mathrm{~L} \mathrm{~mol}^{-1} \mathrm{~s}^{-1}$ which is outside of the diffusion-control regime. These results are presented within this report.

Key words: MRI imagining, fluorescence, binding constant, binding number.

Academic Discipline/Subject Classification/Type: Experimental Biophysical Chemistry.

\section{Council for Innovative Research}

Peer Review Research Publishing System

\section{Journal: Journal of Advances in Chemistry}

Vol. 11, No. 10

www.cirjac.com

editorjaconline@gmail.com, editor@cirjac.com 


\section{INTRODUCTION}

Modern imagining techniques, such as MRI, are able to discriminate between normal and abnormal tissues by generating contrasting images of these organs and/or tissues. One drawback of employing MRI imagining is its relatively low sensitivity. However, the sensitivity can be greatly enhanced by introducing paramagnetic species (i.e. contrasting agents) which can provide a new pathway for water molecules to relax significantly faster and hence generate the desired "contrast" between various tissues. $\mathrm{Gd}^{3+}$ ions are idealas contrasting agents since their unpaired electrons and high magnetic moment provide water protons a new pathway for enhanced relaxation or enhanced relaxivity. ${ }^{1-3} \mathrm{~A}$ number of gadolinium complexes have been employed in magnetic resonance imagingsince their large number of unpaired electrons reduces the spin lattice relaxation time of $\mathrm{H}_{2} \mathrm{O}$ molecules surrounding tissues. ${ }^{4-20}$ Gadolinium complexes are ideal contrasting agents and their water solubility is frequently generated by functionalizing these complexes with groups ranging from $-(\mathrm{OH})_{n},-(\mathrm{COOH})_{n}$, and poly (ethylene glycol $)_{n}$ with $n=8-114$, have been reported. ${ }^{11-15}$ Due to

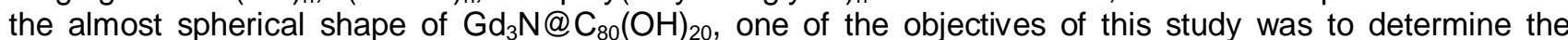
average number of water molecules interacting with this complexes to determine if $\mathrm{Gd}_{3} \mathrm{~N} @ \mathrm{C}_{80}(\mathrm{OH})_{20}-\mathrm{H}_{2} \mathrm{O}$ possess the physical dimensions to cross the blood-brain-barrier allowing for imaging of brain tissues. This research project has the potential of introducing a non-radioactive contrasting agent with the ability to penetrate the blood-brain-barrier. This compound will allow patients to receive a contrasting agent via an easily accessible vein which will permit the contrasting agent to differentiate between healthy brain tissue and potentially dangerous brain tumors.

\section{EXPERIMENTAL SECTION}

$\mathrm{Gd}_{3} \mathrm{~N} @ \mathrm{C}_{80}(\mathrm{OH})_{20}$ was purchased from Luna Innovations and used as received. The number of $-\mathrm{OH}$ hydroxyl groups very in these gadolinium complexes with an average number being twenty. A solution of the probe molecule was prepared using $10 \square \mathrm{L}$ of $\mathrm{Gd}_{3} \mathrm{~N} @ \mathrm{C}_{80}(\mathrm{OH})_{20}$ in $0.75 \mathrm{~mL}$ of $\mathrm{D}_{2} \mathrm{O}$. A fluorescence spectrum of this solution was taken with an excitation line at $350 \mathrm{~nm}$. A single distinctive peak was observed in the region of $\sim 690-710 \mathrm{~nm}$ range. The emission titration was initiated by systematically adding $10 \square \mathrm{L}$ of water beginning with $10 \square \mathrm{L}, 30 \square \mathrm{L}, 60 \square \mathrm{L}, 80 \square \mathrm{L}$ and $100 \square \mathrm{L}$. All fluorescence spectra were taken of these solutions, scanning in the $650-750 \mathrm{~nm}$ range, at room temperature and in a quartz cell $(0.5 \mathrm{~cm}$ path length). The steady-state emission spectra was performed on a PTI QM-4CW fluorimeter system equipped with a xenon lamp, double monochromator for excitation, and a photon counting R928 PMT detector. Since approximately $60 \%$ of the human body is composed of $\mathrm{H}_{2} \mathrm{O}$, it is imperative that the number of water molecules binding to $\mathrm{Gd}_{3} \mathrm{~N} @ \mathrm{C}_{80}(\mathrm{OH})_{20}$ be determine since the number of water molecules bound to the $\mathrm{Gd}_{3} \mathrm{~N} @ \mathrm{C}_{80}(\mathrm{OH})_{20}$ will regulate the size if this complex and will determine if the macromolecule can penetrate the blood-brain-barrier.

\section{RESULTS AND DISCUSSION}

Various types of molecular interactions including collisions, molecular rearrangements, excited state reactions, ground-state complex formation, and energy transfer can lead to fluorescence quenching. ${ }^{21}$ The rate constant, binding constant and binding number can be determined in a straight forward manner by fitting the fluorescence decay as a function of the $\mathrm{H}_{2} \mathrm{O}$ concentration; $\left[\mathrm{H}_{2} \mathrm{O}\right]$. Figure 1 illustrates the decreasing fluorescence intensity indicative of a static quenching mechanism. The main reason for the limited number of contrasting agents is that these contrasting agents must be able to pass the blood-brain barrier (BBB) which places a limit on the molecular size to a range of about $400-500 \mathrm{Da}$ or a molecular surface cross section (MSCS) limit of less than $80 \AA^{2}$. While the molecular weight of the $\mathrm{Gd}_{3} \mathrm{~N} @ \mathrm{C}_{80}(\mathrm{OH})_{20}$ is approximately 1445 $\mathrm{Da}$, its spherical shape, gives a MSCS of $63-69 \AA^{2}$, allowing this contrasting agent to penetrate the BBB. 


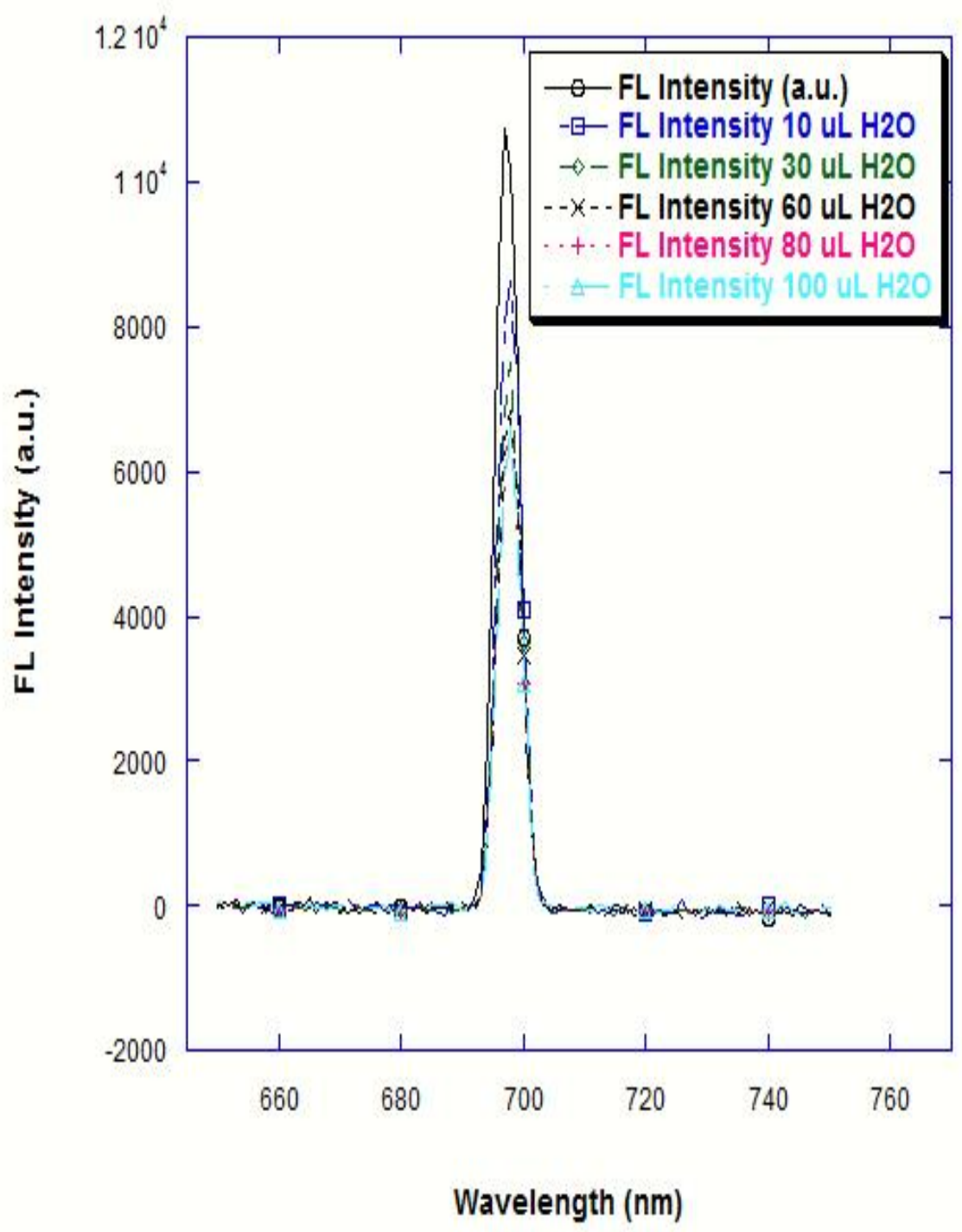

Figure 1: $\mathrm{Gd}_{3} \mathrm{~N} @ \mathrm{C}_{80}(\mathrm{OH})_{20}$ with varying amounts of $\mathrm{H}_{2} \mathrm{O}$

The downward trend in the fluorescence intensity is best characterized by using the well-known Stern-Volmer equation: ${ }^{21}$

$$
\frac{\mathrm{F}_{\mathrm{o}}}{\mathrm{F}}=1+\mathrm{k}_{\mathrm{q}} \tau_{0}[\mathrm{Q}]
$$

where $F_{0}$ and $F$ are the fluorescence intensities in the absence and presence of the quencher, respectively. The product $\mathrm{k}_{\mathrm{q}} \square_{\mathrm{o}}$ is commonly known as the Stern-Volmer constant $\left(\mathrm{K}_{\mathrm{SV}}\right)$ with $\mathrm{k}_{\mathrm{q}}$ being the quenching rate constant, $\square_{0}$ is the average lifetime of the molecule in the absence of the quencher, and [Q] is the concentration of the quencher (i.e. $\mathrm{H}_{2} \mathrm{O}$ ). Since $\square_{0}$ is approximately $10^{-8}$ sin our probe molecule, ${ }^{22}$ a value for the $\mathrm{Gd}_{3} \mathrm{~N} @ \mathrm{C}_{80}(\mathrm{OH})_{20}-\mathrm{H}_{2} \mathrm{O}$ quenching rate constant was obtained from a fit of $\mathrm{F}_{0} / \mathrm{F}$ versus $\left[\mathrm{H}_{2} \mathrm{O}\right]$ as shown in Figure 2. 


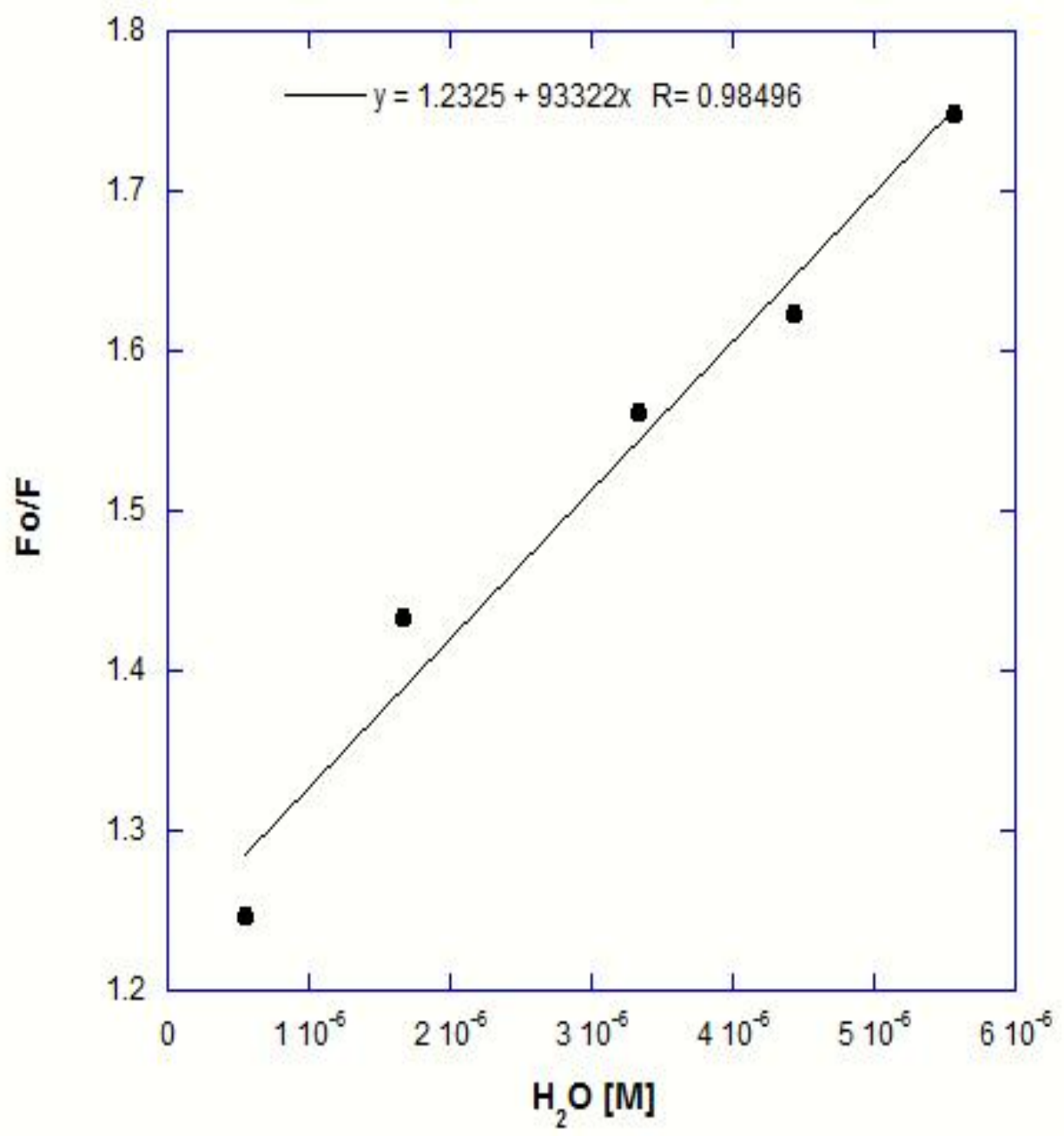

Figure 2: Determination of the quenching rate constant, $\mathrm{k}_{\mathrm{q}}$.

A $k_{q}$ value of $9.33 \times 10^{12} \mathrm{Lmol}^{-1} \mathrm{~s}^{-1}$ suggests the rate constant is outside the diffusion-controlled regime.For this type of quenching, the binding constant $\left(\mathrm{K}_{\mathrm{b}}\right)$ and the number of binding sites $(n)$ can be obtained by using equation $2:^{21}$

$$
\log \left(\frac{\mathrm{F}_{\mathrm{o}}-\mathrm{F}}{\mathrm{F}}\right)=\log \mathrm{K}_{\mathrm{b}}+\operatorname{nlog}[\mathrm{Q}]
$$

Figure 3 illustrates the fit of $\log \left(F_{0}-F / F\right)$ versus $\log [Q]$ with the slope being equal to binding site and the intercept being equated to $\log \mathrm{K}_{\mathrm{b}}$. The calculated fitting coefficient of 0.996 indicates that the interaction between $\mathrm{Gd}_{3} \mathrm{~N} @ \mathrm{C}_{80}(\mathrm{OH})_{20}$ and $\mathrm{H}_{2} \mathrm{O}$ agrees exceptionally well with the binding model as described by equation (2). 


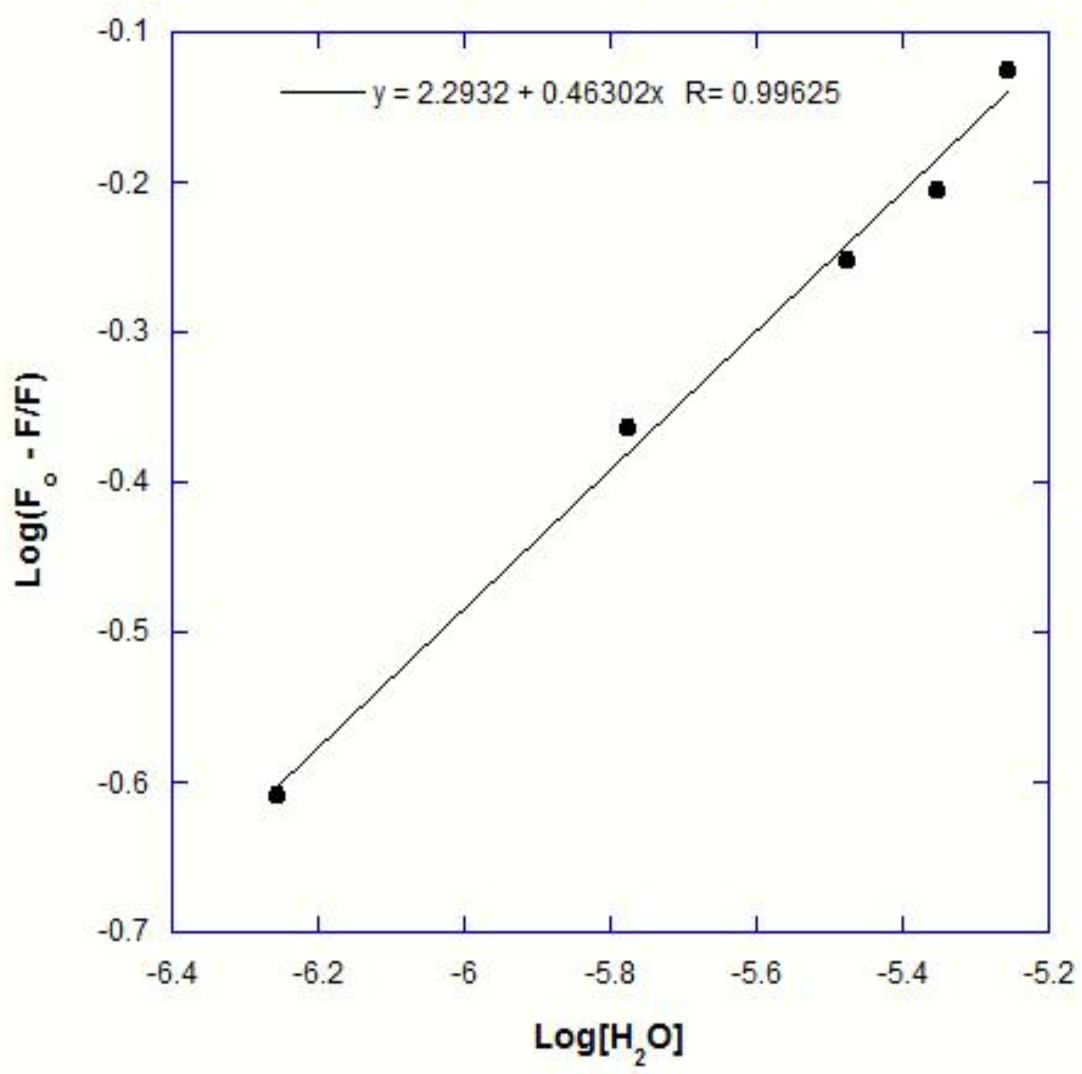

Figure 3: Determination of binding sites and $\mathrm{K}_{\mathrm{b}}$.

Interestingly, $\mathrm{n}$ is approximately equal to 0.5 suggesting the rate constant is very fast generating an average binding site of less than one. Binding site values between 0.5 and 0.7 are commonly rounded to $\approx 1.0$. $^{23}$ However, caution must be exercised since interactions between water and $\mathrm{Gd}_{3} \mathrm{~N} @ \mathrm{C}_{80}(\mathrm{OH})_{20}$ are ensemble averages. The binding constant was found to be $1.96 \times 10^{2} \mathrm{~L} \mathrm{~mol}^{-1}$, several orders of magnitude smaller than protein-nanoparticle complexes but in the same order of magnitude as interactions between human serum albumin (HAS) and small organic acids. ${ }^{24,25}$ The binding constant suggests the interaction is not particularly long-lived which gives rise to the fractional value for the binding site. The hydroxyl groups on $\mathrm{Gd}_{3} \mathrm{~N} @ \mathrm{C}_{80}(\mathrm{OH})_{20}$ can interact, via hydrogen-bonding, with the water molecules generating an effective bridge which enhances electron transfer via the commonly known phenomenon of proton coupled electron transfer. ${ }^{26}$

\section{CONCLUSIONS}

In summary, the first ever recorded fluorescence spectrum of $\mathrm{Gd}_{3} \mathrm{~N} @ \mathrm{C}_{80}(\mathrm{OH})_{20}$ is reported. Our data indicated the $\mathrm{H}_{2} \mathrm{O}-\mathrm{Gd}_{3} \mathrm{~N} @ \mathrm{C}_{80}(\mathrm{OH})_{20}$ interactions led to fluorescence quenching via a static quenching mechanism. The binding constant, $\mathrm{K}_{\mathrm{b}}$, was found to be of the same magnitude as interactions between human serum albumin and small organic acid but quite different, several orders of magnitude smaller, than protein nanoparticle complexes. Surprisingly, the binding site number, $\mathrm{n}$, was found to round to 0.5 , which in cases like this, is rounded to a whole number of one. The data indicated an extremely fast rate constant on the order of $10^{12} \mathrm{~L} \mathrm{~mol}^{-1} \mathrm{~s}^{-1}$ which is outside of the diffusion-control regime. Since $\mathrm{Gd}_{3} \mathrm{~N} @ \mathrm{C}_{80}(\mathrm{OH})_{20}$, is practically a spherical molecule, the fact that the binding number " $\mathrm{n}$ " is one, indicates that the $\mathrm{Gd}_{3} \mathrm{~N} @ \mathrm{C}_{80}(\mathrm{OH})_{20}-\mathrm{H}_{2} \mathrm{O}$ binding complexwill possess the correct physical dimensions to cross the blood-brainbarrier allowing for imaging of brain tissues allowing for patients to receive a contrasting agent via an easily accessible vein which will permit the contrasting agent to differentiate between healthy brain tissue and potentially dangerous brain tumors. 


\section{References}

[1] Bottrill, M., Kwok, L., Long, N. J. Lanthanides in magnetic resonance imaging. Chem. Soc. Rev. 2006, 35, 851-862.

[2] Caravan, P. Protein-Targeted Gadolinium-Based Magnetic Resonance Imaging (MRI) Contrast Agents: Design and mechanism of Action. Acc. Chem. Res., 2009, 42, 851-862.

[3] Villaraza, A. J. L., Bumb, A.,Brechbiel, M. W. Macromolecules, Dendrimers, and Nanomaterials in Magnetic Resonance Imaging: The Interplay between Size, Function, and Pharmacokinetics. Chem. Rev., 2010, 110, 29212959.

[4] Caravan, P., Ellison, J. J., McMurry, T. J., Lauffer, R. B. Gadolinium (III) chelates as MRI contrasting agents: structure, dynamics, and applications. Chem. Rev., 1999, 99, 2293-2352.

[5] Lauffer, R. B., Paramagnetic metal complexes as water proton relaxation agents for NMR imaging: theory and design. Chem. Rev., 1987, 87, 901-927.

[6] Sieber, M. A., Pietsch, H., Walter, J., Haider, W., Frenzel, T,Weinmann, H. J. A preclinical study to investigate the development of nephrogenic systemic fibrosis: A possible role for gadolinium -based contrast media. Invest. Radiol.,2008, 43, 65-75.

[7] Grobner, T., Gadolinium-a specific trigger for the development of nephrogenicfibrosingdermopathy and nephrogenic systemic fibrosis? Naphrol Dial., 2006, 21, 1104-1108.

[8] Shu, C. Y., Zhang, E. Y., Xiang, J. F., Zhu, C. F., Wang, C. R., Pei, X. L., Han, H. B. Aggregation studies of the watersoluble gadofullerene magnetic resonance imaging contrast agent: $\left[\mathrm{Gd} @ \mathrm{C}_{82} \mathrm{O}_{6}(\mathrm{OH})_{16}\left(\mathrm{NHCH}_{2} \mathrm{COOH}\right)_{8}\right]_{x}$. J. Phys. Chem. B., 2006, 110, 15597-15601.

[9] Shu, C. Y., Gan, L. H., Wang, C. R., Pei, X. L., Han, H. B. Synthesis and characterization of new water-soluble endohedral metallofullerenes for MRI contrast agents. Carbon, 2006, 44, 496-500.

[10] Fatouros, P. P., Corwin, F. D., Chen, Z.J., Broaddus, W. C., Tatum, J. L., Kettenmann, B., Ge, Z., Gibson, H. W., Russ, J. L., Leonard, A. P., Duchamp, J. C., Dorn, H. C. In vitro and in vivo imaging studies of new endohedral metallofullerenes nanoparticle. Radiology,2006, 240, 756-764.

[11] Toth, E., Bolskar, R. D., Borel, A., Gonzalez, G., Helm, L., Merback, A. E., Sitharaman, B., Wilson, L., J. Water-soluble gadofullerenes: Toward high-relaxivity, pH-responsive MRI contrast agents. J. Am. Chem. Soc. 2005, 127, $799-805$.

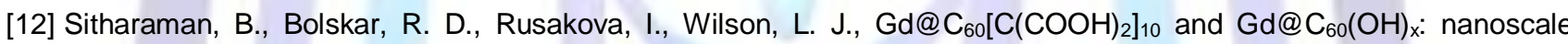
aggregation studies of two metallofullerenes MRI contrast agents in aqueous solution. NanoLett.,2004, 4, $2373-2378$.

[13] Kato, H., Kanazawa, Y., Okumura, M., Taninaka, A., Yokawa, T., Shinohara, H. Lanthanoid endohedral metallofullerenols for MRI contrast agents. J. Am. Chem. Soc.,2003, 125, 4391-4397.

[14] Bolskar, R. D., Benedetto, A. F., Husebo, L. O., Price, R. E., Jackson, E. F.,Wallace, S., Wilson, L. J., Alford, J. M. First soluble $\mathrm{M}_{6} \mathrm{C}_{60}$ derivatives provide enhanced access to metallofullerenes and permit in vivo evaluation of

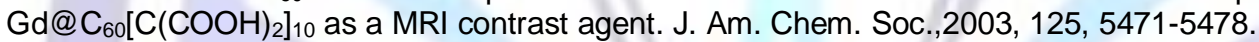

[15] Mikawa, M., Kato, H., Okumura, M., Narazaki, M., Kanazawa, Y., Miwa, N., Shinohara, H. Paramagnetic watersoluble metallofullerenes having the highest relaxivity for MRI contrast agents. Bioconjugate Chem.,2001, 12, 510514.

[16] Shu, C. Y., Corwin, F. D., Zhang, J. F., Chen, Z. J., Reid, J. E., Sun, M. H., Xu, W., Sim, J. H., Wang, C. R., Fatouros, P. P., Esker, A. R., Gibson, H. W., Dorn, H. C. Facile preparation of new gd@fullerene-based magnetic resonace imagining contrast agent with high $\mathrm{H}-1$ relaxivity. Bioconjugate Chem.,2009, 20, 1186-1193.

[17] Shu, C. Y., Wang, C. R., Zhang, J. F., Gibson, H. W., Dorn, H. C., Corwin, F. D., Fatouros, P. P., Dennis, T. J. S. Organophosphonate functionalized $\mathrm{Gd} @ \mathrm{C}_{82}$ as a magnetic resonance imagining contrast agent. Chem. Mater.,2008, 20, 2106-2109.

[18] Shu, C. Y., Ma, X. Y., Zhang, J. F., Corwin, F. D., Sim, J. H., Zhang, E. Y., Dorn, H. C., Gibson, H.W., Fatouros, P. P., Wang, C. R., Fang, X. H. Conjugation of a water-soluble gadolinium endohedral fulleride with an antibody as a magnetic resonance imaging agent. Bioconjugate Chem.,2008, 19, 651-655.

[19] MacFarland, D. K., Walker, K. L., Lenk, R. P., Wilson, S. R., Kumar, K., Kepley, C. L., Garbow, J. R. Hydrochalarones: A novel endohedral metallofullerenes platform for enhancing magnetic resonance imagining contrast. J. Med. Chem.,2008, 51, 3681-3683.

[20] Zhang, E. Y., Shu, C. Y., Feng, L., Wang, C. R. Preparation and characterization of two new water-soluble endohedral metallofullerenes as magnetic resonance imagining contrast agents. J. Phys. Chem. B, 2007, 111, 1422314226.

[21] Lakowicz, J. R. "Principles of Fluorescence Spectroscopy," $3^{\text {rd }}$ ed, Springer, New York, 2006, pp 237- 265.

[22] Lakowicz, J. R; Weber, G. Quenching of fluorescence by oxygen. A probe for structural fluctuations of macromolecules.Biochem., 1973, 12, $4161-4170$. 
[23] Markarian, S.,Aznauryan, M. Study on the interaction between isoniazid and bovine serum albumin by fluorescence spectroscopy: the effect of dimethylsulfoxide. Mol. Biol. Rep.,2012, 39,7559-7567.

[24] Bai, J., Wang, T., Wang, Y., Jiang, X. Effects of nanoparticle surface ligands on protein adsorption and subsequent cytotoxicity. Biomater. Sci.,2014, 2, 493-501.

[25] Liu, Y., Xie, M. X., Jiang, M., Wang, Y. D. Spectroscopic investigation of the interaction between human serum albumin and three organic acids. Spectrochim.Acta Part A, 2005, 61, 2245-2251.

[26] Zhang, G., Wen, Y., Li, Y., Xu, J., Guo, C., Lu, B., Zhu, D. Efficient Fluorescent Recognition of Carboxylates in Aqueous Media Using Facilely Electrosynthesized Poly(9-Aminofluorene). J. Fluoresc., 2013, 23, 1053-1063.

\section{Rodriguez Biography.}

Rodriguez research spans three areas of research including in biotechnology, nanotechnology, and biophysical interests. Research includes the development of fluorescence techniques for the development of non-radioactive contrasting agents capable of penetrating the blood-brain-barrier, the development of dynamic NMR techniques to probe molecular interactions and/or complexes of macromolecules of biological significance, and the development of quantum dot biosensors for diagnostic purposes of prostate cancer.

\section{Rodriguez Photo}

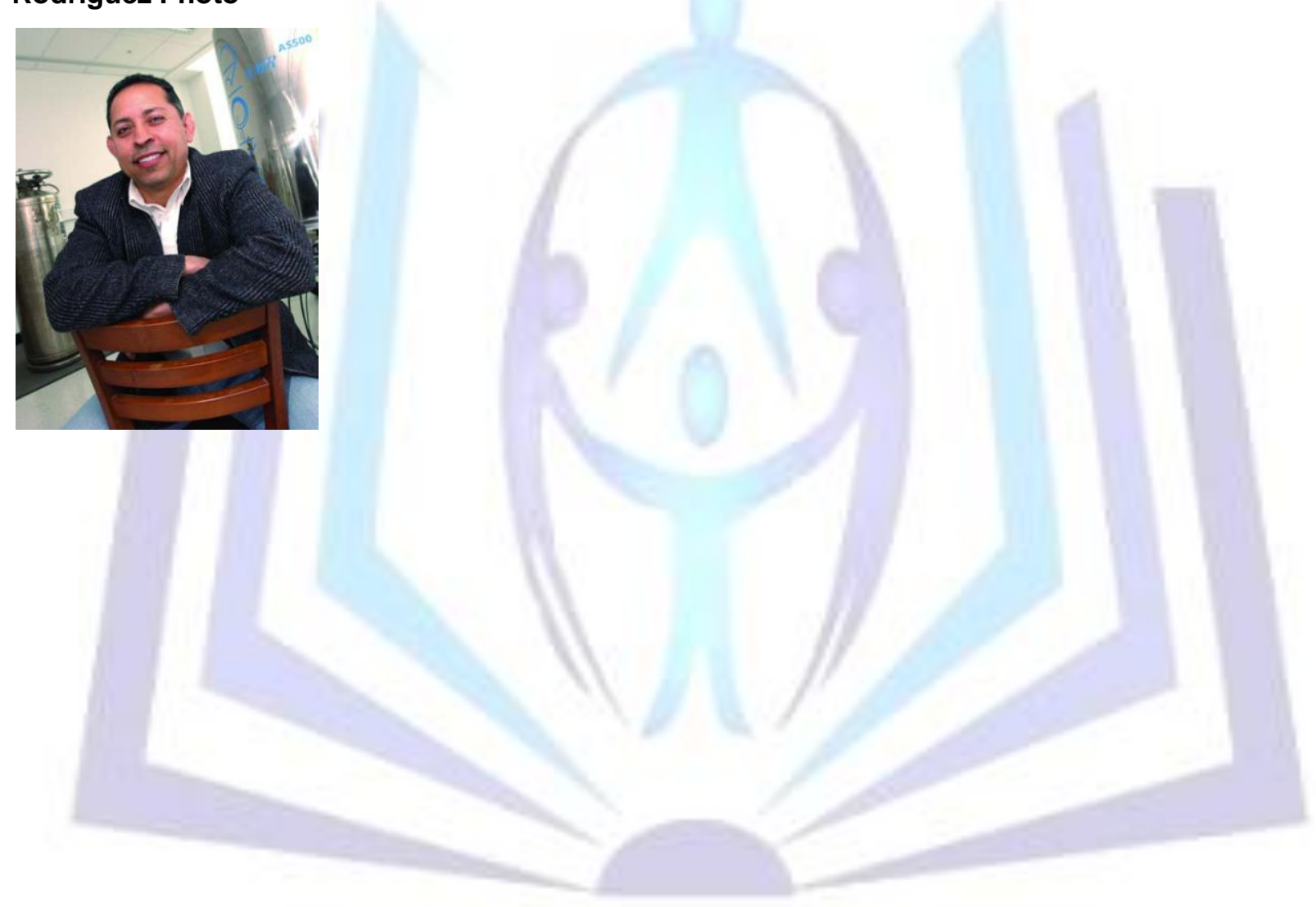

